DOI: 10.1515/ausp-2016-0008

\title{
Reticence in Cicero's Discourse
}

\author{
Levente PAP \\ Sapientia Hungarian University of Transylvania (Miercurea Ciuc, Romania) \\ Department of Humanities \\ paplevente@csik.sapientia.ro
}

\begin{abstract}
M. Tullius Cicero is one of the most prominent figures of ancient rhetoric. His rhetorical speeches are characterized first and foremost by outspokenness and offensiveness and they do not lack in temper either. Since he also dealt with rhetorical theory, Cicero was fully aware of the fact that not only the uttered words and revealed facts hold significance in a rhetorical speech but also concealment and omissions. The latter rhetorical techniques are used mainly in his ad personam attacks. An eloquent example of this is his invective against Piso which I would like to present in more detail.
\end{abstract}

Keywords: Cicero, discourse, omission, in Pisonem, reticence.

Marcus Tullius Cicero's name is strongly related to the heyday of classical Roman literature: the erudite world justly considers him one of the biggest literary, political and philosophical talents of the antiquity. Building a political career was very important to Cicero; to this end, he tried to climb the rungs of cursus honorum as soon and as high as possible. Finally, in 63 BC he reached his goal to become consul. One of his most significant deeds carried out in that capacity was to circumvent the Catilina-conspiracy. Unfortunately, this glorious act led to his downfall, as after the expiration of his mandate he became the victim of political games and ended up being exiled under the pretext of illegal retribution of the Catilina-conspiracy. Cicero's exile lasted until 57 BC, when he could return to the City. However, he continued to make disadvantageous decisions such as supporting Pompeius instead of Caesar in the triumvirs' battle and tried to revenge on his enemies, e.g. on Lucius Calpurnius Piso, consul in 58 BC, who had had a significant part in Cicero's exile. ${ }^{1}$ After his year as a consul was over, Piso

1 At the beginning, Piso had a good relationship with Cicero, the consul of $63 \mathrm{BC}$, and even approved of his strong actions against the Catilinarians, while, however, he also maintained a good relationship with the Catilinian Cethegus. After a while he decided to act against the execution of the Catalinarians: he even supported his fellow consul, Clodius, in his attempt 
obtained the province of Macedonia as a reward for the success of Cicero's exile. During his two-year-long governance he continuously ransacked the province; then finally in 55 BC the senate appointed another governor, Quintius Ancharius instead of him. In his speech delivered in the debate on Piso's recall, Cicero did not spare his enemy at all, which fact was later held against him by Piso after his return from Macedonia. But Cicero, instead of an act of propitiation, wrote his in Pisonem speech. This invective, which does not lack temper at all, uses a big variety of rhetorical means in order to paint the most unfavourable picture of his enemy. One of the techniques or figures used by Cicero is omission.

When we think about Cicero's career as an orator, he does not appear to us as a reticent speaker, especially not in his ad personam attacks. But what could the word "reticence" refer to in the title, then? However weird it might seem, reticence is a significant part of a speech, it could not be defined without the concept of speech. As Sartre puts it, reticence does not mean that one is mute; it rather means that one chooses not to speak, and by this, he speaks after all (quoted in Benyovszky 2006, 10). According to Mikhail Bakhtin, silence is when nothing can be heard (or something cannot be heard), while reticence is when nobody talks (or somebody - a person - does not talk); the concept of "reticence" can only be referred to within the context of humanity (quoted in Benyovszky $2006,10)$. Spoken words have a great influence in rhetoric, but they are not the only means to create effect. Since Cicero also dealt with rhetoric theory besides building his political career, the central topic of his works is the identification of the characteristics of an ideal rhetor. He obviously knew that the ideal orator did not exist; however, he also knew that identifying a set of requirements to strive for could be quite useful. Cicero wrote rhetorical works of real scientific value about an orator's objectives, about his character, about the structure of a speech, the theory of style, etc. ${ }^{2}$

He also dealt with the technique or figure of reticence (reticentia, ocultatio, paraleipsis) and tried to define it. ${ }^{3}$ The interpretation of this rhetorical technique may be easier if we take a look at Cornificius' work entitled Rhetorica ad Herennium, which was written about the same time as ad Inventione, and in which the author describes the figure of omission praeteritio, occultatio (apophasis, paralipsis) as follows:

to exile Cicero. Furthermore, it was during Piso's governance that his fellow consul, Clodius submitted to the senate two laws agains Cicero: lex exilio Ciceronis and lex capite civis Romani. De inventione, De oratore, Partitiones oratoriae, Brutus, De optimo genere oratorum, Orator, Topica (cf. Sumner 1973; Adamik 2012).

3 "[P]ersonarum ficta inductio vel gravissimum lumen augendi; descriptio, erroris inductio, ad hilaritatem impulsio, anteoccupatio; tum duo illa, quae maxime movent, similitudo et exemplum; digestio, interpellatio, contentio, reticentia, commendatio; vox quaedam libera atque etiam effrenatio augendi causa; iracundia, obiurgatio, promissio, deprecatio, obsecratio, declinatio brevis a proposito, non ut superior illa digressio, purgatio, conciliatio, laesio, optatio atque exsecratio. His fere luminibus inlustrant orationem sententiae" (Cicero 1990, III. 205). 
This figure is useful if employed in a matter which is not pertinent to call specifically to the attention of others, because there is advantage in making only an indirect reference to it, or because the direct reference would be tedious or undignified, or cannot be made clear, or can easily be refuted. As a result, it is of greater advantage to create a suspicion by Paralipsis than to insist directly on a statement that is refutable. (Cornificius 1978, IV. 27)

This definition quasi completes and explains Cicero's interpretation. Quintillianus, a later illustrious figure of the ancient theory on rhetoric, enumerates in his handbook those figures of speech which are created by the omission of certain elements: he classifies reticence/omission, or ocultatio not within the category of "figures of speech" but within the "figures of thought" category (Quintilianus 1920, 9.3.97, 99). As we mentioned earlier, Cicero applies this figure of speech - or rather figure of thought - mainly in his ad personam speeches, ${ }^{4}$ and within that category, the post reditum invectives are the ones with an abundant use of this formula (Beasley 1973, 16-17). Earlier invectives of Cicero with similar topic also contain this figure, without any doubt, but not with such a big frequency and efficiency. There are more than ten occasions in in Pisonem where a figure of speech related to reticence occurs (Cicero 1978, 3, 17, 23, 33, 49, 51, 53, 55, 79, 90).

Cicero attacks his enemy from several angles: with one of the targets being Piso's political career, the way he managed - or rather did not manage - to live up to the requirements of the cursus honorum. Cicero, conveniently, describes his own career in contrast with the former's, putting emphasis on the huge differences between the two, so that the audience can easily be convinced about Piso's despicable character. The long list of accusations is composed artfully by the orator: right at the beginning he resorts to an omissio: "But I say nothing of the circumstances under which each of us was elected. I will allow that chance may have been the mistress of the Campus Martius. It is more to the purpose to say how we conducted ourselves in our respective consulships, than how we obtained them" (Cicero 1978, II.4). Behind this "generosity" of not talking about the way each of them got elected to be consuls, lies the bare fact that even Cicero himself had to give up on some of his principles, ${ }^{5}$ at least if we accept that Quintus Cicero's Commentariolum serves as the handbook (David 1973, 239-277)

$4 \quad$ Mainly Verrinae and Orationes in Catilinam.

5 For example, this is what he says about the blanditia, suggested by Quintus: "Nec vero neglegenda est fama, nec mediocre telum ad res gerendas existimare oportet benevolentiam civium; quam blanditiis et adsentando colligere turpe est" (Cicero 1935, XVII. 61); "Ut igitur et monere et moneri proprium est verae amicitiae et alterum libere facere, non aspere, alterum patienter accipere, non repugnanter, sic habendum est nullam in amicitiis pestem esse maiorem quam adulationem, blanditiam, adsentationem; quamvis enim multis nominibus est hoc vitium notandum levium hominum atque fallacium ad voluntatem loquentium omnia, nihil ad veritatem" (Cicero 1935, XXV. 91.). 
of Marcus Cicero's election campaign. ${ }^{6}$ With that in mind, it is understandable why Cicero did not insist on entering into details about this circumstance, because by doing so he would have offered a good opportunity for his enemy to counterattack.

There was yet another fact for Cicero to consider when opting for this tack: in case he had talked openly about the way Piso's political career started, pointing out its negative aspects, he could not have avoided mentioning Caesar's name, Piso's son-in-law, who had actively supported Piso's campaign not just because of a sense of duty towards his father-in-law, but because he had had high hopes to control legislation through the prospect of a Pompeius-Gabinius consulate (Pap 2015, 21). True enough, Cicero mentions pointedly that some luck was also necessary for someone to land in such a high position. He does not wish to further discuss who was lucky and when, only makes some hints - but, as a homo novus, he refrains from going into details, especially given the fact that he would like to remain on good terms with Caesar. He will affirm this idea in a broader context later (Cicero 1978, 81, 82). He continues to purposefully avoid dissecting those actions which could be linked to Caesar. In two instances he cuts short some elaborate reasoning saying that he wishes to avoid those: "Why need I say more on this subject?" (Cicero 1978, 79), "But I will say nothing of what is past" (Cicero 1978, 80). However, by opting for this technique of reticence, Cicero briefly reminds the audience of facts known by everyone in Rome, so it is not necessary for him to talk about these in detail; at the same time, this way he can avoid getting himself in an awkward situation in front of Caesar. It is more convenient for him to exploit the contrast between the savior of the state - the one who eliminated Catilina - and the enemy of the state, the one who plots against Caesar: why would a brilliant politician such as Cicero compare his own activities as a consul to an insignificant period such as that of Piso's consulhood: "For why should I speak of my consulship? whether as to the manner in which it was obtained, or in which it was conducted" (Cicero 1978, II. 3).

Obviously, he will not forego the opportunity to highlight his own actions as a consul at the expense of his adversary. Piso committed lots of heinous crimes but the orator chooses to generously leave some of these unmentioned: "For, I say nothing of the fact of a consul issuing an edict, that the senate should not obey a resolution of the senate; an action than which none more shameful can either be done or imagined" (Cicero 1978, VIII. 17).

$6 \quad$ Quintus thinks of blanditia as a necessary means and even recommends its use: "Sed opus est magnopere blanditia, quae etiam si vitiosa est et turpis in cetera vita, tamen in petitione necessariast; etenim cum deteriorem aliquem adsentando facit tum improba est, cum amiciorem non tam vituperanda, petitori vero necessaria est, cuius et frons et vultus et sermo ad eorum quoscumque convenerit sensum et voluntatem commutandus et accommodandus est" (Cicero 2002, XI. 42.). For more see: Shackleton (2002), Németh (2005), Nótári (2006), Voinea (2014). 
As we could see, Cicero was not driven in the least by piousness or generosity when he chose to avoid mentioning important details. In fact, by highlighting his desire to avoid mentioning these, he directs the attention of the audience to the question and affirms that it is a shameful thing for someone not to obey the decisions of the senate. ${ }^{7}$ At the same time, his desire to avoid mentioning certain details also calls attention to the fact that this important component could even be neglected, as the previously mentioned evidence has already created sufficient grounds for incrimination. Exercising the supreme power of a consul has not increased the reputation of the incriminated person either. Cicero reveals that Piso was only concerned about outward appearance while he was a consul, and he considered outwardly factors the essence of holding a function. After having listed such severely condemning facts, he continues to reveal even more onerous details - while between these two parts of his speech, Cicero shines again as a pious accuser, as he uses an ambiguous sentence and feigns avoidance: "But I pass over all those points" (Cicero 1978, X. 23). Regardless of the interpretation, Cicero keeps his promise neither before nor after this sentence; instead, he continues to depict the nefariousness of Piso as a consul. Perhaps he would rather not go into details regarding the fact that Piso's position as a Macedonian proconsul has not been voted properly by the senate, but by the concilium plebis ${ }^{8}$ (Nisbet 1961). The fact that, in Cicero's eyes, the two previously mentioned laws are a result of collusions of powers of some sort, cannot question the lawfulness of Piso's position as a proconsul. Because of this, further details should not be mentioned, reckons the orator. When questions raised by the orator are not answered, or seemingly not answered, it means that, once again, he applies some strategy which is also part of reticence. Why should the glorious consul of the year 64 BC compare his brilliant year in office with such a lowly person's? "If that most disturbed period, when I was forced to depart from the city, is superior to the time of your greatest triumph, why need I compare our other circumstances, which in your case were all full of disgrace, and in mine of dignity?" (Cicero 1978, XV. 33).

However, according to his previous invitation - "But to proceed!" (Cicero 1978, XV. 33) - he will choose not to be so generous as to forget about his own dignified and popular persona which he managed to remain even during his exile, and to glorify himself at the expense of the shamefully exiled Piso, who lost his leading position and was forced to flee. In this context it is unnecessary to even mention obvious facts. Interestingly enough, though, when he expresses his wish to avoid mentioning these facts, he includes some details that he could not possibly overlook:

7 Perhaps once again he avoids on purpose to talk about the fact that valid laws should be obeyed, as this was Cicero's main crime in the case of the Catilina-execution.

8 During their meetings, plebeians brought their own laws called plebiscita. Their decisions became generally applicable beginning with the announcement of lex Hortensia (B.C. 287). 
Why should I speak of my arrival in the different towns? why of the crowds of men who thronged out to meet me? why of the way in which the fathers of families with their wives and children gathered together to greet me? why of those days which were celebrated by everyone on my arrival and return, as if they had been solemn festival days of the immortal gods? (Cicero 1978, XXII. 51)

In spite of the fact that Cicero is the only contemporary source of knowledge for us about his own triumphant return, the enthusiastic welcome he mentions is credible in the given political context. At the same time, the apparent avoidance of giving details of his triumphant return may be considered a proof of his modesty. That is, it may be - if only he did not exclaim a few lines below:

That one day was to me like an immortality, on which I returned to my country, and saw the senate which had come forth to meet me, and the whole Roman people; while Rome itself, torn, if I may so say, from its foundations, seemed to come forward to embrace her saviour. Rome, which received me in such a manner that not only all men and all women of all classes, and ages, and orders of society, of every fortune and every rank, but that even the walls and houses of the city and temples appeared to be exulting. (Cicero 1978, XXII. 52)

While he talks about Piso's return, once again he is forced to be reticent - yes, he is forced to be so, as it is impossible to give the names of those, for example, who welcomed Piso, as such persons simply did not exist. Ironic wording (cf. Haury 1951) is not strange at all to the writing; the following question provides a great example for it: "But why do I count up all the people who did not go forth to meet you? when I say that scarcely any one did, not even of that most officious body of candidates for office, though they had been repeatedly warned and requested to do so, both on that very day, and many days before" (Cicero 1978, XXIII. 55).

Cicero is in the possession of thorough knowledge regarding the points of accusation, and yet he does not mention many capital crimes: "Why need I bring forward your investigations into capital charges, your agreements with criminals, your most iniquitous condemnation of some, your most profligate acquittal of others?" (Cicero 1978, XXXVI. 87). He reckons that he will forego mentioning a lot of details, but he cannot resist the temptation to drop a few hints about the atrocities Piso committed in several provinces (trafficking with weapons, leather hoarding scandals, shady business deals, etc.). However, these arguments are not entirely credible - that is, as Nisbet $(1961,175-176)$ remarks, the points of the accusation are tendentious. The capital charges, about which the orator remains 
silent, could not have been much more objective either - in fact, they were not objective at all, and the lack of a solid foundation would have offered grounds for Piso's counterattack. The reduction of the crimes to a mere list, as well as the pious avoidance of giving details, increase the amount of crimes attributed to the adversary, which the audience might accept right there and then, given the lack of opportunity to verify the statements.

I say nothing of the gold for a crown, which tormented you a long time, while at one time you were inclined towards it and at another time unwilling to take it [...]; I say nothing of the commissions which you scattered at random over the provinces; I say nothing of the number of vessels, or of the sum total of the plunder you acquired; I say nothing of the system under which you levied and extorted all the corn; I say nothing of your having stripped both nations and individuals of their liberties, even though they had had those liberties given them by name as rewards, not one of all which things is not carefully provided against and expressly forbidden to be done by the Sullan law. (Cicero 1978, XXXVII. 90)

The triumphant deserves the gold wreath and the triumphal march, and it is every Roman soldier's and Roman politician's desire to become such a triumphant. The ironic remark "while at one time you were inclined towards it and at another time unwilling to take it" refers to Piso's Epicurean philosophical views.

Piso, who uses his power to commit atrocities and is an enemy of the state, is not only despicable as a functionary, but also as a private person. One of the favourite topics of the invective is exposing and publicizing his personal vices. The Arpinum native will not forego the great opportunity to do this in the present speech either. After disclosing the official atrocities and crimes, he starts discussing the trespasses of Piso's personal life. The disclosure begins with an attempt to use reticence again, as Piso leads such an outrageous life, that "horribile dictu: And these things I scarcely venture to say. I am afraid that there may be someone who does not clearly see his enormous wickedness, concealed as it is under his impenetrable countenance; still I will say it" (Cicero 1978, VI.12). He seemingly seeks to spare the audience from finding out details about Piso's horrible lifestyle, but in fact he only stirs up their interest and encourages people to start gossiping. A head of a state who spends his nights at taverns drinking to oblivion, rolls around in the dirt, belches and manifests signs of hangover, would be a favourite target of tabloids in our days as well. Romans used to listen with the same mean gusto to such juicy details of private lives which an honest man would rather not talk about - but he, Cicero simply has to.

As a conclusion, we can state that Cicero uses the possibilities offered by the figure of speech of reticence or ocultatio masterfully. He applies it in accordance 
with the given situation, when revealing cases that are difficult to reason about, and their complete analysis and dissection would not necessarily contribute to the success of the orator. As a consequence, he keeps himself and others safe from useless and dangerous confrontations. At the same time, when he refers implicitly to scandals and lawlessness, it seems more proactive for the pious orator to refrain from discussing such events in detail. Instead, it seems more salutary to announce his silence in regards to the respective event in order to excite the audience. Even if the audience cannot remember the ominous events anymore, they would thoroughly investigate the stories, which in many cases do not lack some piquancy either. The irony that permeates such speeches was useful for Cicero to make his adversaries less credible and gain the favour of the audience.

\section{Works Cited}

Adamik Tamás. 2012. Cicero összes retorikaelméleti múvei. [Cicero’s Complete Works on the Theory of Rhetorics.] Bratislava: Kalligram.

Bakhtin, Mikhail. 1986. "Beszédelméleti jegyzetek." ["Notes on the Theory of Speech."] In A beszéd és a valóság [Speech and Reality], trans. Orosz István, 517-547. Bratislava: Madách.

Beasley, Mary Fowler. 1973. “It's What You Don't Say: Omissio in Cicero's Speeches.” Southern Speech Communication Journal vol. 39. no. 1: 11-20.

Benyovszky, Krisztián. 2006. "Az elhallgatás alakzatai." ["The Figures of Speech of Reticence.”] Kalligram. vol. 15. no. 11-12.

http://www.kalligram.eu/Kalligram/Archivum/2006/XV.-evf.-2006.-novemberdecember/KOeLTESZET-ES-RETORIKA/Az-elhallgatas-alakzatai (Last accessed 19 April 2016)

Cicero, Marcus Tullius. 1935. De amicitia. [On Friendship.] Ed. and trans. William Armistead Falconer. Loeb Classical Library. Cambridge, MA: Harvard University Press.

Cicero, Marcus Tullius. 1978 [1909]. In Pisonem. [Against Piso.] Ed. and trans. Albert Curtius Clark. Oxford: Calderon.

Cicero, Marcus Tullius. 1990. De oratore. [On the Orator.] Ed. Augustus S. Wilkins. Hildesheim, Zürich, New York: Georg Olms Verlag.

Cicero, Marcus Tullius. 2011. Cicero Against Verres, 2.1.53-86. Trans. Ingo Gildenhard. Cambridge: Open Book Publishers.

Cicero, Quintus Tullius. 2002. Handbook of Electioneering. Ed. and trans. Shackleton Bailey, David Roy. Loeb Classical Library. Cambridge, MA: Harvard University Press. 
Cornificius, Quintus. 1978 [1954]. Rhetorica ad Herennium. [Rhetoric for Herennius.] Trans. Hary Caplan. Loeb Classical Library. Cambridge, MA: Harvard University Press.

David, Jean-Michel et al. 1973. "Le 'Commentariolum Petitionis' de Quintus Cicéron." ["The 'Commentariolum Petitionis' of Quintus Cicero.”] ANRW vol. I no. 3: 239-277.

Haury, Auguste. 1951. L'ironie et l'humor chez Ciceron. [Irony and Humour at Cicero.] Leiden: Brill.

Németh, György. 2005. "Hogyan nyerjük meg a választásokat?” ["How to Win the Elections?”] Médiakutató no. 1 http://www.mediakutato.hu/cikk/2005_01_tavasz/01_hogyan_nyerjuk (Last accessed 19 April 2016)

Nisbet, Robert George Murdoch. 1961. Cicero: In L. Calpurnium Pisonem Oratio. [Against Piso.] Oxford: Calderon Press.

Nótári Tamás. 2006. Hogyan nyerjük meg a választásokat? Quintus Tullius Cicero: A hivatalra pályázók kézikönyve. [How to Win the Elections? The Handbook of Those Who Seek to Obtain an Office.] Trans. Tamás Nótári. Ed. György Németh. Szeged: Lectum.

Pap, Levente. 2015. Cicero: Piso Ellen. [Cicero Against Piso.] Cluj-Napoca: Erdélyi Múzeum Egyesület.

Quintilianus, Marcus Fabius. 1920. Institutio Oratoria. [Institutes of Oratory.] Loeb Classical Library. Cambridge: Harvard University Press.

Sartre, Jean Paul. 1969. Mi az irodalom? [What Is Literature?] Trans. Árpád Vígh. Budapest: Gondolat.

Shackleton Bailey, D. R. 2002. Cicero. Letters to Quintus and Brutus - To Octavian - Invectives - Handbook of Electioneering. Loeb Classical Library. Cambridge, MA: Harvard University Press.

Sumner, Graham Vincent. 1973. The Orators in Cicero's Brutus: Prosopography and Chronology. Toronto and Buffalo: University of Toronto Press.

Voinea, Alexandru Lucian. 2014. "Communication and Manipulation to Cicero." Journal of Romanian Literary Studies no. 5: 218-227. 